Brit. J. vener. Dis. (1961), 37, 70.

\title{
RECENT TRENDS IN MALE GONORRHOEA IN MANCHESTER*
}

\author{
BY \\ S. M. LAIRD \\ Director, St. Luke's Clinic, and V.D. Department, Royal Infirmary, Manchester \\ Advisor in Venereology, Manchester Regional Hospital Board
}

Gonorrhoea has been on the increase in England and Wales since 1955 . In 1959 , there were 31,344 newly diagnosed cases, the highest level since 1947 (Ministry of Health, 1960). As gonorrhoea is commonly an infection of the promiscuous in the cities and larger towns, the national figures do not always reflect the position in all treatment centres; increases in the cities may obscure a lowered incidence in the clinics serving small towns and country areas (Laird and Morton, 1959). The position with regard to gonorrhoea in Manchester and its densely-populated industrial conurbation would be expected to mirror trends in the national figures, which themselves are heavily influenced by the experience of the great cities. This expectation has in fact materialized and the gonorrhoea figures for Manchester have broadly followed those of England and Wales as a whole. In the past year, however, the incidence of male gonorrhoea in the Manchester clinics has shown a sustained downward trend which was first obvious in the figures for the fourth quarter of 1959. The incidence of gonorrhoea tends to vary seasonally and, in general, is higher in the second and third quarters of the year. The number of cases in the third quarter is usually augmented by "imported" infections acquired outside Manchester by holidaymakers. For this reason it is more accurate to compare the totals for similar quarters each year. Table I shows the quarterly figures for male gonorrhoea in England and Wales and in Manchester from 1955 to the second or third quarter of the year 1960 .

Table II and Fig. 1 (opposite) show the trend in male gonorrhoea in England and Wales and in Manchester as a percentage of the 1955 figures.

These percentages indicate that, whilst the incidence of male gonorrhoea in the clinics of England and Wales as a whole continues to rise, that of the clinics in Manchester has fallen significantly during the year ending September 30, 1960. This falling incidence in Manchester is restricted to gonorrhoea: other new cases (classified as non-gonococcal urethritis, other conditions requiring treatment, and

\footnotetext{
* Short paper read to the M.S.S.V.D. in London on November 25, 1960
}

TABLE I

MALE GONORRHOEA IN THE CLINICS OF ENGLAND AND WALES AND OF MANCHESTER

\begin{tabular}{|c|c|c|c|c|c|c|c|}
\hline Quarter & Area & 1955 & 1956 & 1957 & 1958 & 1959 & 1960 \\
\hline \multirow[t]{2}{*}{1 st. } & $\begin{array}{l}\text { England } \\
\text { and Wales }\end{array}$ & 2,841 & 3,225 & 4,067 & 4,849 & 5,050 & 5,724 \\
\hline & Manchester & 258 & 247 & 309 & 346 & 406 & 294 \\
\hline \multirow{2}{*}{ 2nd. .. } & $\begin{array}{l}\text { England } \\
\text { and Wales }\end{array}$ & 3,361 & 3,970 & 4,682 & 5,551 & 6,517 & 6,506 \\
\hline & Manchester & 354 & 325 & 361 & 443 & 463 & 400 \\
\hline \multirow{2}{*}{3 rd } & $\begin{array}{l}\text { England } \\
\text { and Wales }\end{array}$ & 4,226 & 4,748 & 5,805 & 6,400 & 7,383 & $\begin{array}{c}\text { Not } \\
\text { avail- } \\
\text { able }\end{array}$ \\
\hline & Manchester & 399 & 317 & 413 & 484 & 493 & 420 \\
\hline \multirow{2}{*}{ 4th } & $\begin{array}{l}\text { England } \\
\text { and Wales }\end{array}$ & 3,580 & 4,371 & 5,061 & 5,607 & 5,996 & $\begin{array}{c}\text { Not } \\
\text { avail- } \\
\text { able }\end{array}$ \\
\hline & Manchester & 279 & 335 & 385 & 406 & 315 & $\begin{array}{l}\text { Not } \\
\text { avail- } \\
\text { able }\end{array}$ \\
\hline
\end{tabular}

TABLE II

TREND IN MALE GONORRHOEA FROM 1956 TO THE SECOND AND THIRD QUARTER OF 1960 IN ENGLAND AND WALES AND IN MANCHESTER AS A PERCENTAGE OF THE 1955 FIGURES

\begin{tabular}{|c|c|c|c|c|c|c|}
\hline Quarter & Area & 1956 & 1957 & 1958 & 1959 & 1960 \\
\hline \multirow{2}{*}{ 1st. $\quad .}$. & $\begin{array}{l}\text { England } \\
\text { and Wales }\end{array}$ & +13 & +43 & +71 & +78 & +101 \\
\hline & Manchester .. & -4 & +20 & +34 & +57 & +14 \\
\hline \multirow{2}{*}{ 2nd. .. } & 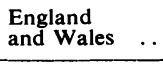 & +18 & +39 & +65 & +94 & +94 \\
\hline & Manchester ... & -8 & +1 & +25 & +21 & +10 \\
\hline \multirow{2}{*}{ 3rd. } & $\begin{array}{l}\text { England } \\
\text { and Wales } \ldots \\
\end{array}$ & +12 & +37 & +51 & +75 & $\begin{array}{c}\text { Not } \\
\text { avail- } \\
\text { able }\end{array}$ \\
\hline & Manchester .. & -21 & +3 & +21 & +24 & +5 \\
\hline \multirow{2}{*}{ 4th. .. } & $\begin{array}{l}\begin{array}{l}\text { England } \\
\text { and Wales } \ldots\end{array} \\
\end{array}$ & +22 & +41 & +56 & +67 & $\begin{array}{c}\text { Not } \\
\text { avail- } \\
\text { able }\end{array}$ \\
\hline & Manchester .. & +20 & +38 & +45 & +13 & $\begin{array}{c}\text { Not } \\
\text { avail- } \\
\text { able }\end{array}$ \\
\hline
\end{tabular}

other conditions not requiring treatment) show no similar downward trend (Table III, overleaf). 


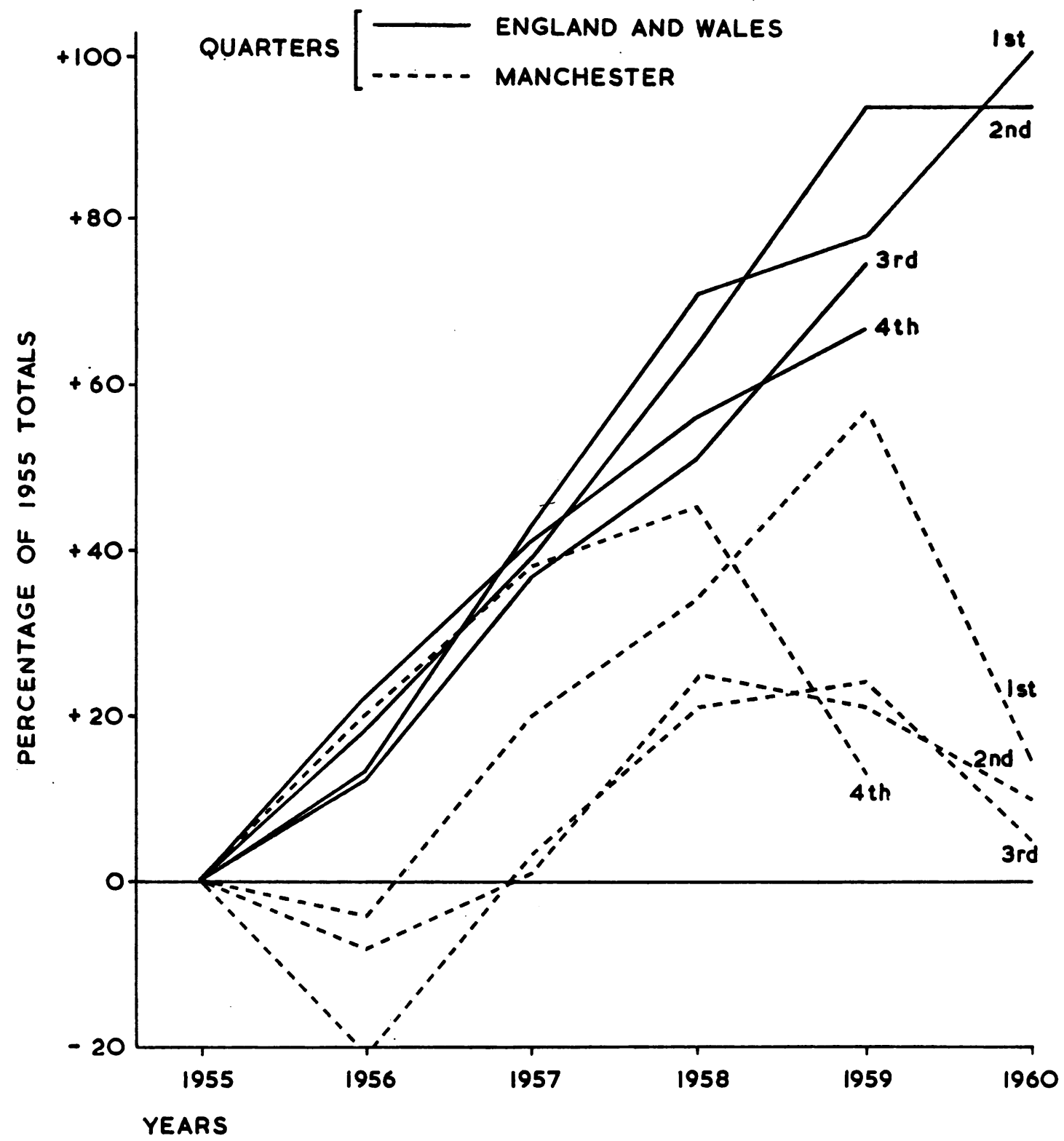

Fig. 1.-Trends in male gonorrhoea in England and Wales and in Manchester from the first quarter of 1955 to the third quarter of 1960 .

The position in the neighbourhood of Manchester, in the peripheral clinics of the Manchester Regional Hospital Board area (Table IV, overleaf), shows a very small overall decline in male gonorrhoea during the year ending September 30,1960, compared with that during the year ending September 30, 1959.
The increase of 33 cases in Preston is considered to be due to the recent arrival there of West Indian immigrants. These peripheral clinics show, with a few minor exceptions, that the trend for non-gonococcal urethritis and other conditions is upward. 
TABLE III

MALE CASES OF VENEREAL DISEASE IN MANCHESTER CLINICS, QUARTERLY TOTALS, FROM THE END OF 1958 TO THE THIRD OUARTER OF 1960

\begin{tabular}{|c|c|c|c|c|c|}
\hline \multirow{3}{*}{ Year } & \multirow{3}{*}{ Quarter } & \multicolumn{4}{|c|}{ Diagnosis } \\
\hline & & \multirow{2}{*}{ Gonorrhoea } & \multirow{2}{*}{$\begin{array}{c}\text { Non-gonococcal } \\
\text { Urethritis }\end{array}$} & \multicolumn{2}{|c|}{ Other Conditions } \\
\hline & & & & Requiring Treatment & $\begin{array}{c}\text { Not Requiring } \\
\text { Treatment }\end{array}$ \\
\hline 1958 & 4 & 406 & 165 & 171 & 250 \\
\hline \multirow{4}{*}{1959} & 1 & 406 & 130 & 115 & 258 \\
\hline & 2 & 463 & 195 & 170 & 303 \\
\hline & 3 & 493 & 199 & 157 & 284 \\
\hline & 4 & 315 & 172 & 156 & 280 \\
\hline \multirow{3}{*}{1960} & 1 & 294 & 165 & 141 & 237 \\
\hline & 2 & 400 & 203 & 242 & 385 \\
\hline & 3 & 420 & 240 & 184 & 243 \\
\hline
\end{tabular}

TABLE IV

RISE OR FALL IN NUMBERS OF NEW CASES OF VENEREAL DISEASE IN PERIPHERAL CLINICS, 1959-1960

\begin{tabular}{|c|c|c|c|c|}
\hline \multirow[b]{3}{*}{ Clinic } & \multicolumn{4}{|c|}{ Diagnosis } \\
\hline & \multirow[b]{2}{*}{ Gonorrhoea } & \multirow{2}{*}{$\begin{array}{l}\text { Non- } \\
\text { gonococcal } \\
\text { Urethritis }\end{array}$} & \multicolumn{2}{|c|}{ Other Conditions } \\
\hline & & & $\begin{array}{l}\text { Requiring } \\
\text { Treatment }\end{array}$ & $\begin{array}{c}\text { Not } \\
\text { Requiring } \\
\text { Treatment }\end{array}$ \\
\hline Blackburn ... & +3 & +1 & +5 & +29 \\
\hline Burnley & -15 & +3 & +3 & +6 \\
\hline Bury & -22 & +7 & - & +17 \\
\hline Bolton & +15 & +30 & +21 & +30 \\
\hline Wigan & - & +8 & +16 & -10 \\
\hline Blackpool .. & -33 & +16 & +25 & +12 \\
\hline Lancaster .. & +9 & - & +7 & -12 \\
\hline Barrow & -7 & +11 & -7 & +14 \\
\hline Oldham & -34 & +1 & +3 & +18 \\
\hline Rochdale .. & +6 & +5 & +3 & +30 \\
\hline Ashton & -1 & +9 & -9 & +24 \\
\hline Stockport .. & -12 & +18 & -12 & +8 \\
\hline Macclesfield & - & -1 & -1 & -4 \\
\hline Preston & +33 & +27 & +27 & +30 \\
\hline Kendal & - & -1 & -2 & -4 \\
\hline Crewe & +2 & -4 & -1 & +10 \\
\hline Balance .. & -56 & +130 & +78 & +198 \\
\hline
\end{tabular}

\section{Discussion}

This downward trend in male cases of gonorrhoea in the Manchester clinics first became evident in the fourth quarter of 1959 and has now continued for 12 months. In contrast, the figures for England and
Wales continued to rise in the fourth quarter of 1959 and the first quarter of 1960; those in the second quarter of 1960 were nine less than in the same quarter of 1959.

To the best of my knowledge the only significant change in the Manchester environment has been a sharp decline in street prostitution since the Street Offences Act came into operation in August, 1959. The transformation in Manchester in streets hitherto traditionally associated with "street-walkers" was quite dramatic. The street prostitute almost disappeared (Table V); some gave up, at least temporarily, but many simply moved into pubs, clubs, cafés, and dance halls. Until August, 1959, street prostitution was an important factor in the spread of gonorrhoea in Manchester, intercourse with a prostitute being admitted by 30 per cent. of men with gonorrhoea (Laird, 1956, 1958). The great reduction in the number of prostitutes in the streets of Manchester has greatly diminished the number of "spurof-the-moment" exposures which has hitherto formed a significant proportion of sexual exposures

Table V

ARRESTS FOR PROSTITUTION IN THE CITY OF MANCHESTER, 1959 AND 1960

\begin{tabular}{l|c|c}
\hline \multirow{2}{*}{ Month } & \multicolumn{2}{|c}{ Year } \\
\cline { 2 - 3 } & 1959 & 1960 \\
\hline January & 106 & 53 \\
February & 136 & 55 \\
March & 117 & 38 \\
April & 123 & 35 \\
May & 144 & 36 \\
June & 222 & 40 \\
July & 242 & 29 \\
August & 110 & 26 \\
September & 29 & 29 \\
October & 48 & \\
\hline
\end{tabular}


amongst men in Manchester. The erstwhile street prostitute now operates much more often in pubs, clubs, cafés, and dance halls, but such contacts require a more deliberate action on the part of the male than is the case when he is accosted in the street.

\section{Summary}

Male gonorrhoea in Manchester has declined in the year ending September 30,1960. This decline is attributed to the greater control of street prostitution made possible since August, 1959, by the operation of the Street Offences Act.

I am indebted to the Chief Constable of Manchester for supplying data about offences by prostitutes in the City, and to my colleagues, Drs. Dawson, Mackay,
Read, and Silver, for information regarding the trends in the peripheral clinics.

\section{REFERENCES}

Laird, S. M. (1956), Brit. J. vener. Dis., 32, 181. (1958). Ibid., 34, 137.

- and Morton, R. S. (1959). Ibid., 35, 187.

Ministry of Health (1960). "Annual Report of the Chief Medical Officer for 1959". Cmnd. 1207. H.M.S.O., London. (Brit.J. vener. Dis., 1961, 37, 74).

\section{Résumé}

L'incidence de la gonorrhée parmi la population masculine de Manchester a diminué pendant l'année qui s'est terminée le 30 septembre 1960. Ce déclin est attribué au contrôle plus strict de la prostitution sur la voie publique depuis l'application du Street Offences Act en août 1959. 